\title{
miR-29a is a Potential Protective Factor for Fibrogenesis in Gluteal Muscle Contracture
}

\author{
Ri ZHOU ${ }^{1}$, Shiyou REN $^{1} *$, Canfeng LI $^{1}$, Xintao ZHANG ${ }^{1}$, Wentao ZHANG \\ * These authors contributed equally to this work. \\ ${ }^{1}$ Department of Sports Medicine and Rehabilitation, Peking University Shenzhen Hospital, \\ Shenzhen, Guangdong, China
}

Received September 1, 2019

Accepted February 24, 2020

Epub Ahead of Print May 29, 2020

\begin{abstract}
Summary
Circulating miRNAs have been proposed as the effective diagnostic biomarkers for muscular fibrosis-associated diseases. However, circulating biomarkers for early diagnosis of contracture muscles are limited in gluteal muscle contracture (GMC) patients. Here we sought to explore the abnormally expressed miRNAs in plasma and contraction bands of GMC patients. The results showed miR-29a-3p expression in plasma and contraction bands tissue was significantly reduced in GMC patients compared with normal control. Cell viability and levels of proliferation-associated protein cyclin D1 and cyclindependent-kinase 2 (CDK2) were powerfully inhibited by miR-29a mimics and enhanced by miR-29a inhibitor compared with negative control. Furthermore, miR-29a mimics effectively impeded, while miR-29a inhibitor enhanced the expression of collagen I and collagen III, followed by the secretion of transforming growth factor $\beta 1$ (TGF- $\beta 1$ ), TGF- $\beta 3$ and connective tissue growth factor (CTGF) in primary human contraction bands (CB) fibroblasts. The miR-29a-3p negatively regulated the expression of TGF- $\beta 1$ through binding to the $3^{\prime}$ UTR region of SERPINH1 (encoding heat shock protein HSP47), but had no effect on Smad2 activity. The miR-29a-3p was inversely correlated with HSP47 in contraction bands tissue from GMC patients. Collectively, miR-29a was notably depressed and regulated cell viability and fibrosis by directly targeting HSP47 in GMC, which suggest that circulating miR-29a might be a potential biomarker for early diagnosis and provides a novel therapeutic target for GMC.
\end{abstract}

\section{Key words}

Gluteal muscle contracture • miR-29a • Fibrosis • HSP47 • TGF- $\beta 1$

\section{Corresponding author}

W. Zhang, Department of Sports Medicine, Peking University Shenzhen Hospital, No. 1120 Lianhua Road, Futian District, Shenzhen 518036, Guangdong, China. E-mail: zhangwt2007@sina.cn

\section{Introduction}

Gluteal muscle contracture (GMC) is characterized by contracture of the gluteal muscles and related fascia. The patients clinically present as abduction and external rotation of the affected hip and unable to keep the knees together while squatting, and the patients also have difficulties in maintaining a normal gait (Aggarwal et al. 2005, Scully et al. 2015). The disease is much more frequent in China with an incidence rate of $1 \%$ to $2.5 \%$ (Liu et al. 2009). GMC not only causes a hip deformity with abnormal hip motion in different degrees but also reported to have femoral head osteonecrosis (Liu et al. 2011). Current methodologies for GMC diagnosis are confined in some physical examinations including Ober's sign, flattened or coneshaped buttock and dimpling of skin in the buttock area. Magnetic resonance imaging (MRI) and computed tomography (CT) scan are also being used for probing GMC; unfortunately, all of them have a disadvantage of not being able to predict early (Rai et al. 2017). The surgical treatment is only the effective way to alleviate the symptom of GMC at present (Rai et al. 2018, $\mathrm{Xu}$ et al. 2014). However, intraoperative hemorrhage and postoperative complications such as infection, incision scar and incomplete remission or recurrence of symptoms 
are problems that cannot be ignored (Zhang et al. 2017). Therefore, it is urgent to search for a new biomarker for early diagnosis of GMC that might provide a reliable basis for the definitive treatment of GMC.

Multiple etiologies have been reported to cause the GMC that leads to chronic fibrosis of the gluteal muscles (Al Bayati et al. 2016, Zhao et al. 2009). There is proliferation of fibroblasts and immoderate expression of collagen in the extracellular matrix of GMC (Zhao et al. 2010). Some studies uncovered that fibrotic muscle of the GMC patients is associated with the accumulation of transforming growth factor $\beta 1$ (TGF- $\beta 1$ ), type I and type III collagen (Oleas-Santillan et al. 2019, Zhao et al. 2010). TGF- $\beta 1$ can independently act as a potent fibrogenic cytokine for tissue fibrosis by stimulating fibroblasts growth (Zhang et al. 2015). TGF- $\beta 1 / \mathrm{Smad} 2$ signaling pathway plays an extremely important role during fibrotic processes of gluteal muscles. Once activated by TGF- $\beta 1$, Smad 2 can cause the increase of matrix proteins and decrease of matrix-degrading proteases, which are involving in the process of extracellular matrix (ECM) generation and tissue fibrosis (Yang et al. 2011). Furthermore, Other fibrotic related protein such as HSP47, a collagen-specific molecular chaperone, can promote the effects of TGF- $\beta 1$ on the abduction of expression of collagen type I, collagen type IV in human renal cortical cells (Xiao et al. 2012). In human primary tenon's fibroblasts, HSP47 removal can notably inhibit TGF- $\beta 1$-induced differentiation from Tenon's fibroblasts to myofibroblasts (Hong et al. 2012). These data suggest that correlation of HSP47 and TGF- $\beta 1$ participates in the fibrotic processes. However, the relationship of HSP47 and TGF- $\beta 1$ are blurry in the progression of GMC.

Numerous evidence indicates that miRNAs is of utmost importance to the progress of muscular fibrosis (Hesse et al. 2019, Zanotti et al. 2018). For instance, the expression of miR-29 and miR-21 was much more abundant in Duchenne fibroblasts than in Duchenne muscle and myoblasts (Zanotti et al. 2015). The miRNAs expression pattern of Duchenne muscular dystrophy patients also shows the upregulation of miR-31, miR-34c, miR-206, miR-335, miR-449, and miR-494 in adductor muscles (Greco et al. 2009). Muscular dystrophy (MD) accompanied by fibrosis present an increased expression of miR-21 in the mouse of Laminin-deficient congenital muscular dystrophy (LAMA2-CMD) (Moreira Soares Oliveira et al. 2017). Some studies also demonstrated that the expression of miR-30c and miR-181a increased
7- and 6-fold, respectively, in the serum of muscular dystrophy patients (Llano-Diez et al. 2017). The profile of circulating miRNA of muscular dystrophy patients in serum shows that miR-1, miR-133a and miR-206 are up-regulated, which is coincident with abnormal expression in muscle-specific miRNAs (Mizuno et al. 2011). These above studies suggest that serum miRNAs and muscle miRNAs are potentially useful and reliable biomarkers for early diagnosis in muscle fibrosis-related diseases. Nevertheless, there are no evidence that circulating miRNA or other biomarkers for early diagnosis in GMC progression.

Herein, we demonstrated that the expression of miR-29a was lower in plasma and contraction bands in GMC patients than that in normal control. The miR-29a regulation affected the cells viability and fibrosis of fibroblasts by regulating HSP47 and TGF- $\beta 1$ expression. The expression of miR-29a was negatively associated with the transcription and protein level of HSP47. These findings suggest that miR-29a is likely to be a useful biomarker for early diagnosis and monitoring prognosis of GMC.

\section{Materials and Methods}

\section{Subjects}

This study was approved by the ethics committee of PEKING University Shenzhen Hospital, and all patients had signed informed consent. Blood samples were collected from 13 healthy people and 18 GMC patient ranging from March 2017 to June 2018 in PEKING University Shenzhen Hospital. Briefly, peripheral venous blood samples were collected from individual and stored in EDTA anticoagulant tube. Each sample $(5 \mathrm{ml})$ was diluted with an equal volume red blood cell lysis buffer (R1010, Solarbio, China) for $15 \mathrm{~min}$ on ice. After centrifugation at $400 \times \mathrm{g}$ for $10 \mathrm{~min}$, the supernatant containing lysate of red blood cell was removed and the bottom sediment (leukocyte) was resuspended by PBS buffer. The mixture was centrifugated at $400 \times \mathrm{g}$ for $10 \mathrm{~min}$ again to collect bottom sediment followed by the extraction of total RNA by using Trizol regents. Besides, fresh contraction bands (CB) tissues were collected from GMC patients $(n=8)$ with $\mathrm{CB}$ releasing surgery according to previous study. Then $\mathrm{CB}$ tissues were used for next experiment. The clinical features of the cohort were presented in Table 1 and Table 2 . 
Table 1. Clinical features in the assay analyzed miRNAs profiles of plasma and tissue.

\begin{tabular}{lcc}
\hline & Control & Gluteal muscle contracture (GMC) \\
\hline Gender & & 5 \\
Male & 7 & 13 \\
Female & 6 & $26.06 \pm 1.243$ \\
Age (years) & $38.15 \pm 3.55$ & $54.7 \pm 2.316$ \\
Weight $(\mathrm{kg})$ & $62.38 \pm 2.787$ & \\
Disease type & & 18 \\
Bilateral GMC & 0 & 0 \\
Unilateral GMC & 0 & Arthroscopic release \\
Treatment & 1 & \\
\hline
\end{tabular}

Table 2. Clinical features of patients in the correlation analysis assay.

\begin{tabular}{lc}
\hline & Gluteal muscle contracture (GMC) \\
\hline Gender & \\
Male & 4 \\
Female & 4 \\
Age (years) & $27.88 \pm 1.597$ \\
Weight (kg) & $58.21 \pm 4.734$ \\
Disease type & 8 \\
Bilateral GMC & 0 \\
Unilateral GMC & \\
Treatment & Arthroscopic release \\
\hline
\end{tabular}

\section{Immunohistochemical staining}

Fresh contraction bands (CB) and adjacent normal muscle samples of GMC patients $(n=8)$ were collected and fixed with $4 \%$ paraformaldehyde for $24 \mathrm{~h}$ at $4{ }^{\circ} \mathrm{C}$. After dehydrating with graded ethanol, tissues were vitrified by dimethyl benzene and embedded in paraffin. The $5 \mu \mathrm{m}$ sections of paraffin-embedded tissue were dewaxed in xylene for $10 \mathrm{~min} 3$ times and rehydrated in an ethanol gradient. Antigen retrieval was performed with high-pressure method in fresh sodium citrate solution for $15 \mathrm{~min}$, followed by blocking in $5 \%$ Bovine Serum Albumin (BSA) for $1 \mathrm{~h}$ at room temperature. Blocked slides were then incubated with the primary antibody against HSP47 (Ab109117, 1:200, Abcam, USA) diluted with $5 \%$ BSA overnight at $4{ }^{\circ} \mathrm{C}$. Next day, the slides were washed in $1 \times$ phosphate buffered solution-Tween 20 (PBST) for $5 \mathrm{~min} \times 3$ times and incubated with specific-secondary antibody (PV9001, ZSGB-BIO, China) according to the manufacture's instruction. Finally, HSP47 positive cells were visualized by using standard diaminobenzidine (DAB) chemiluminescence reagents (ZLI 9018, ZSGB-BIO, China). After mounting with glycerin, HSP47-positive cells were observed under inverted biological microscope and counted using Image $\mathrm{J}$ software.

\section{Cell isolation and culture}

Fresh CB tissues from GMC patients were used for human $\mathrm{CB}$ fibroblasts isolation. Briefly, contraction bands were separated into blocks with $2 \times 2 \mathrm{~mm}^{2}$ and washed with sterile PBS buffer for 3 times. Then, the small blocks were placed into $10-\mathrm{cm}$ tissue culture dishes and incubated with DMEM (11320-033, GIBCO, USA), $10 \%$ FBS (10091-148, GIBCO, USA), $10 \mu \mathrm{g} / \mathrm{ml}$ gentamicin (15750078, Invitrogen, USA), and $10 \mathrm{mg} / \mathrm{ml}$ amphotericin B (R01510, Invitrogen, USA) overnight. Cells were incubated in at $37^{\circ} \mathrm{C}$ in a humidified incubator in $5 \% \mathrm{CO}_{2}$. Culture medium was changed three times each week. The cells adopted in this study were confined in 3-5 generations. Human CB fibroblasts were harvested when cells at 80-90\% confluence using $0.1 \%$ trypsin and were seeded in 6-well plate. After $24 \mathrm{~h}$, miR-29a mimic and miR-29a inhibitor (RiboBio, China) were transfected in cells by lipo2000 (11668-027, Invitrogen, USA) for $48 \mathrm{~h}$ and then performed further examinations. 
Real-time quantitative PCR ( $q R T-P C R)$

Total RNA from leukocyte and contraction band tissues were extracted by Trizol (15596026, Invitrogen, USA) under the manufacture's introduction. Then $1 \mu \mathrm{g}$ RNA was reverse-transcribed into cDNA by using cDNA reverse transcription kit (4368813, Applied Biosystems,
USA) according to the specification. Real-time quantitative PCR (qRT-PCR) was performed to measure the relative mRNAs expression of target genes by using SYBR Green (AQ131-01, Transgen Biotech, China). All data were normalized to the control of GAPDH. PCR primer sequence was shown in Table 3.

Table 3. Primer sequences of $q R T-P C R$.

\begin{tabular}{lcc}
\hline Gene name & Forward (5'-3') & Reverse (5'-3') \\
\hline Collagen I & GTCGAGGGCCAAGACGAAG & CAGATCACGTCATCGCACAAC \\
Collagen III & TGGTCCCCAAGGTGTCAAAG & GGGGGTCCTGGGTTACCATTA \\
$\alpha$ SMA & GTGTTATGTAGCTCTGGACTTTGAAAA & GGCAGCGGAAACGTTCATT \\
SERPINH1 & CGCCATGTTCTTCAAGCCA & CATGAAGCCACGGTTGTCC \\
$\beta$-actin & CTCCATCCTGGCCTCGCTGT & GCTGTCACCTTCACCGTTCC \\
\hline
\end{tabular}

For miRNA detection assay, total RNA from blood samples and tissues were extracted as described above. Then $10 \mathrm{ng}$ RNA was reverse-transcribed into cDNA by TaqMan ${ }^{\mathrm{TM}}$ MicroRNA Reverse Transcription Kit (4366596, ThermoFisher Scientific, USA). TaqMan Universal PCR Master Mix was used to perform RT-PCR amplification by Applied Biosystems ABI 7500 (ThermoFisher Scientific, USA). U6 was served as the internal control for qRT-PCR assay. All primer information of miRNAs was presented in Table S1. Stem-loop RT primer (custom RT primer) was used to perform reverse transcription. The universal stem-loop sequence was as follow: GTCGTATCCAGTGCAGGGTCCGAGGTATTCGCACTGGATACGAC. After realtime PCR reaction, specific RT primers and probes were used for fluorescence quantification.

\section{CCK8 assay}

Primary human CB fibroblasts were cultured in 96-well plates at a density of $3 \times 10^{3}$ cells/well. After $12 \mathrm{~h}$, miR-29a mimics and inhibitors were transfected in cells by lipo2000 (11668-027, Invitrogen, USA) for $8 \mathrm{~h}$ followed by changing fresh culture medium. After 24, 48, 72 and $96 \mathrm{~h}$, cells were added in $10 \mu \mathrm{l}$ CCK 8 assay (C0037, Beyotime, China) reagents for $4 \mathrm{~h}$ and the cells viability were measured by a Multiscan plate reader (MK3, Thermo Fisher Scientific, Waltham, MA, USA) at the wavelength of $450 \mathrm{~nm}$.

\section{ELISA assay}

Levels of TGF- $\beta 1$, TGF- $\beta 3$ and CTGF in cell supernatant were measured by ELISA assay. In brief, when human $\mathrm{CB}$ fibroblasts cells were transfected with miR-29a mimics or miR-29a inhibitors for $48 \mathrm{~h}$, culture mediums were collected and centrifugated at $2500 \times \mathrm{rpm}$ for $10 \mathrm{~min}$, the supernatants of mediums were used to detect the concentration of fibrogenic cytokines according to the manufacture's instruction of TGF- $\beta 1$ kits (88-8350-22, Invitrogen, USA), TGF- $\beta 3$ kits (KA4402, Abnova, USA) and CTGF kits (ABIN6730903, Abnova, USA). Absorbance readings were taken at the wavelength of $405 \mathrm{~nm}$ using a Multiscan plate reader.

\section{Dual-luciferase assay}

The human normal untranslated regions sequence (3' UTR) of SERPINH1 (HSP47) containing miR-29a binding site and its mutated $3^{\prime}$ UTR sequence were synthesized by PCR amplification and inserted into the pYr-MirTarget basic vector. $293 \mathrm{~T}$ cells were seeded in 24 -well plates with a density of $2 \times 10^{4}$ cells/well. After $12 \mathrm{~h}$, cells were transfected with $50 \mathrm{nM}$ miR-29a mimic or negative controls by using Lipo2000, followed by co-transfection with $50 \mathrm{ng}$ of the wild type (WT) or 3' UTR-mutant of HSP47, respectively. Luciferase activities were proceeded with Luciferase Reporter Detection kits (E1910, Promega, USA) at $48 \mathrm{~h}$ posttransfection. Each sample was duplicated at least 3 times.

\section{Western blotting}

Total proteins were extracted by using RIPA protein lysate (89900, Invitrogen, USA). $50 \mu \mathrm{g}$ total protein were used to determine the levels of proliferationand fibrosis-related protein. All samples were performed at least 3 independent experiments. Primary antibodies 
information were as follows: cyclin D1 (55506S, Cell Signaling, USA), CDK2 (2546S, Cell Signaling, USA), P-SMAD2 (18338S, Cell Signaling, USA), SMAD2 (5339S, Cell Signaling, USA), TGF- $\beta 1$ (ab92486, Abcam, USA), collagen I (ab34710, Abcam, USA), Collagen III (ab7778, Abcam, USA), HSP47 (Ab109117, 1:200, Abcam, USA), GAPDH (AF0006, Beyotime, China).

\section{Statistical analyses}

All experiments were repeated at least 3 times. Correlation analysis was performed by Pearson's coefficient using SPSS software. Relative quantitative analysis of protein was proceeded using Quantity One software. All values were presented as means $\pm \mathrm{SD}$, and these data were statistically analyzed by a two-tailed Student's $t$-test and two-way ANOVA by using GraphPad Prism 5.0 software. Statistically significant differences were accepted at $P<0.05$.

\section{Results}

miR-29a is apparently reduced in GMC patients miRNAs, as direct post-transcriptional repression, play an essential role in muscular dysfunction (Amin et al. 2015, Friedman et al. 2009). However, its role in the progression of GMC remains unclear. In the present study, we first evaluated the expression pattern of muscular dysfunction- and fibrosis-related miRNAs such as miR-29a-3p, miR-26a-5p, miRNA-133a-3p, miRNA206, miRNA-222-3p, miRNA-342a-3p and miRNA$378 a-5 p$ in GMC patients. The results showed that only miR-29a-3p among these miRNAs was drastically declined in the plasma of GMC patients compared with normal individuals (Fig. 1A).

Furthermore, the expression of these miRNAs were determined in contraction bands tissues of GMC patients and the paired adjacent normal muscle samples. As shown in Figure 1B, the levels of miR-29a-3p and miR-342a-3p was decreased, whereas the expression of miR-133a-3p and miR-222-3p presented a significant increase in GMC patients' tissues compared to that in adjacent normal muscle (Fig. 2B). Therefore, these findings prove that the reduced miR-29a-3p in plasma is consistent with the expression pattern in contraction bands of GMC patients, which suggest that miR-29a-3p is possibly an effective diagnostic and prognostic circulating marker for GMC.
A

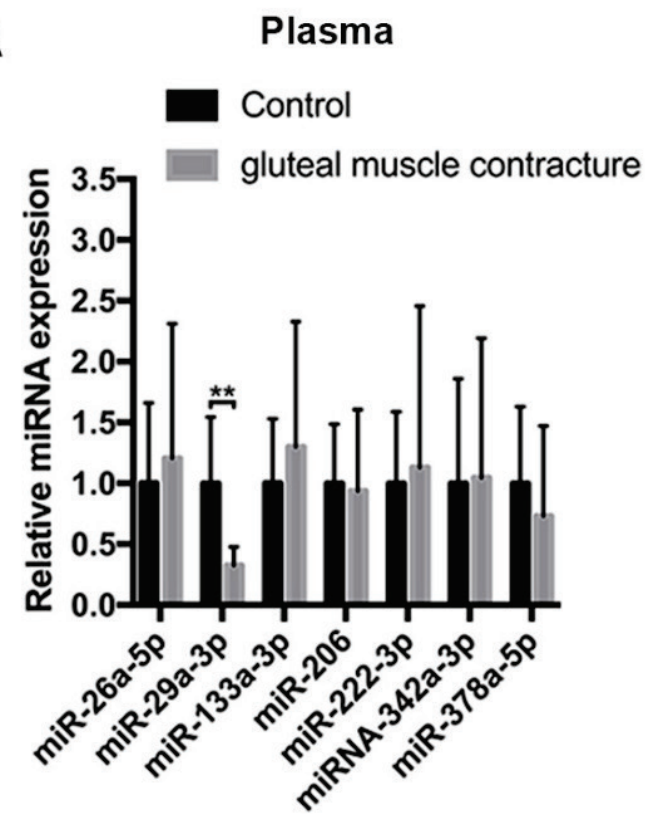

B
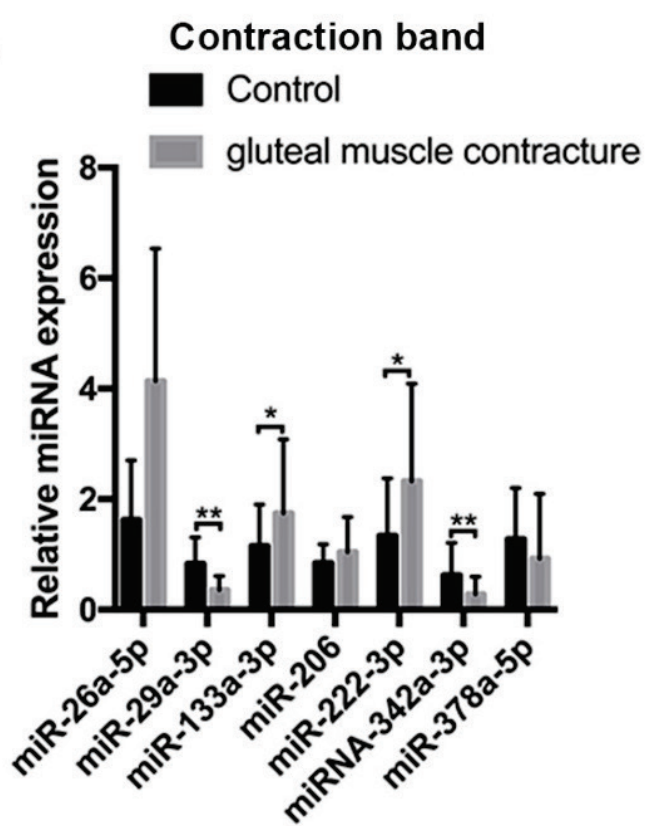

Fig. 1. The miRNAs profiles of plasma and tissue in human normal individuals and Gluteal muscle contracture (GMC) patients. MiRNAs profiles including miR-26a-5p, miR-29a-3p, miR-133a-3p, miR-206, miR-222-3p, miRNA-342a-3p and miR-378a-5p of plasma (healthy samples: $n=13$; GMC patients: $n=18)$ in human normal individuals and GMC patients $(\mathbf{A})$ and gluteal musculature tissue $(n=8)(B)$ in contraction bands and adjacent normal muscle samples as determined by qRT-PCR. * indicates normal individuals vs. GMC patients or adjacent normal muscle vs. contraction bands of GMC patients. Data represent the means \pm SD of three experiments and analyzed by GraphPad Prism 5.0 software using two-way ANOVA. * $P<0.05$. $* * P<0.01$. 
miR-29a impairs cell proliferation of human contraction bands fibroblasts

It has been demonstrated that decreased cell viability of muscle fibroblasts contribute to the improvement of muscular dystrophy and muscle fibrosis (Morin et al. 1995). To explore the biological functions of miR-29a on human contraction bands (CB) fibroblasts, we firstly performed CCK 8 assay to determine the role of miR-29a on cell ability of human CB fibroblasts. Once transfected with miR-29a mimics, cells showed a significant decline at Day 2 and Day 3 compared with control mimics and a more apparently reduced at Day 4 compared with human $\mathrm{CB}$ fibroblasts transfected with control mimics (Fig. 2A). However, miR-29a inhibitors markedly enhanced cell viability of fibroblasts compared to negative control cells at Day 2 and the promotion effect became more significant at Day 3 and Day 4 (Fig. 2A). Besides, we further determined the impact of miR-29a on cell cycle-related proteins of fibroblasts. After cells were treated with miR-29a mimics for $48 \mathrm{~h}$, the proteins of cyclin D1 and cyclin-dependent kinase 2 (CDK2) were powerfully crippled, which expression were significantly enhanced in fibroblasts incubated with miR-29a inhibitor compared with negative inhibitor group (Fig. 2B). These results showed that miR-29a inhibition promotes cell viability of primary human contraction bands (CB) fibroblasts possibly by regulating cyclin D1 and CDK2.
A

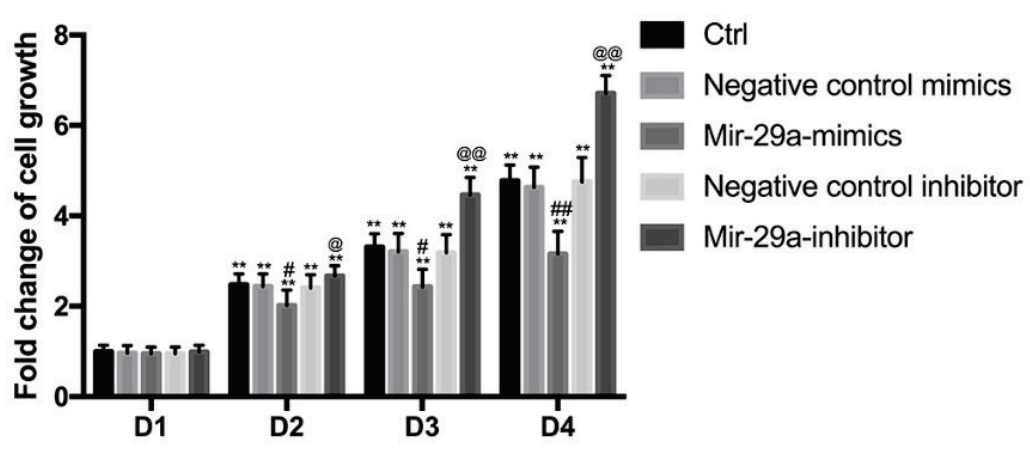

B

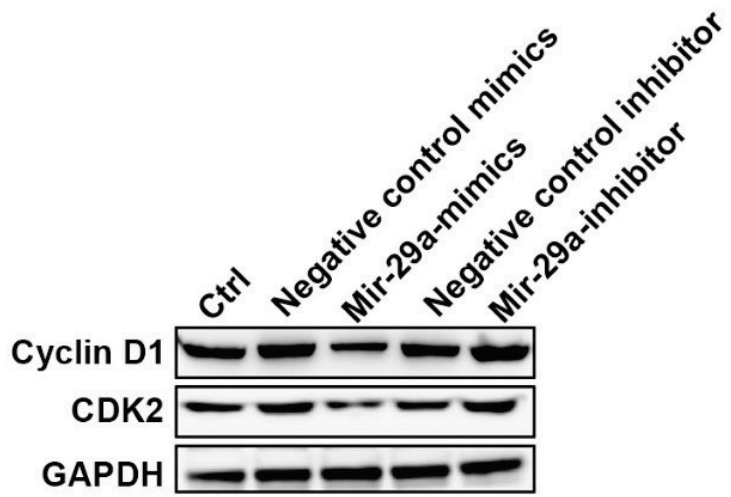

Cyclin D1/GAPDH

CDK2/GAPDH
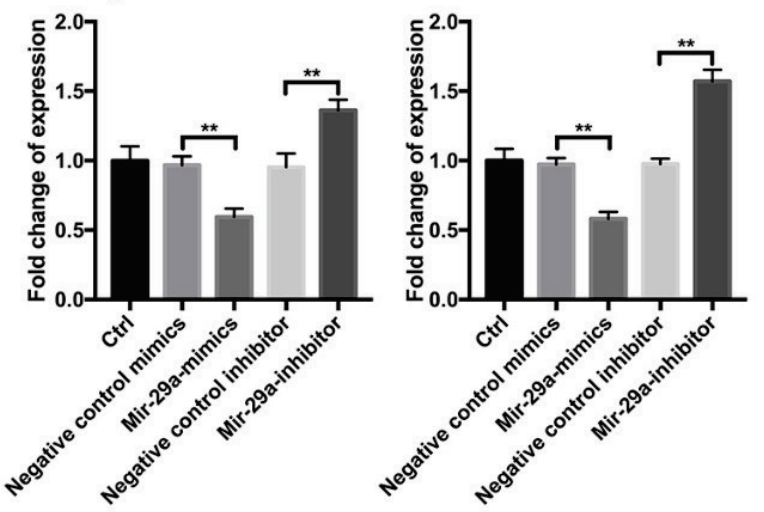

Fig. 2. Effects of miR-29a on cell viability in primary human contraction bands fibroblasts. (A) Human contraction bands $(\mathrm{CB})$ fibroblast cells were transiently transfected with miR29a mimics $(50 \mathrm{nM})$, miR-mimic NC, miR-29a inhibitors, or miR-inhibitor NC for $48 \mathrm{~h}$. Then cell viability of different group analyzed by CCK8 experiment at Day 1 to Day 4. (B) Cell cycle related protein cyclin D1 and CDK2 were evaluated by western blotting in human CB fibroblast cells. Relative quantitative analysis of protein was proceeded using Quantity One software. Protein expression of collagen I and collagen III were normalized by glyceraldehyde 3-phosphate dehydrogenase (GAPDH). Ctrl, control; NC, negative control. $*$ indicates each group vs. the former day of each group. \# indicates miR-29a mimics groups vs. negative control mimics groups a more significant difference with $P<0.05$; \# indicates miR-29a mimics groups vs. negative control mimics groups. @ indicates miR-29a inhibitors groups vs. negative control inhibitor groups. Data represent the means \pm SD of three experiments, each experiment performed in triplicate. Fold change of cell growth was analyzed by GraphPad Prism 5.0 software using two-way ANOVA. ${ }^{*}$ and ${ }^{\circledR}, P<0.05$. **, \#\# and $@ @, P<0.01$. 
miR-29a hampers the fibrotic process in human CB fibroblasts

GMC is featured by gluteal muscle fibrosis, which is mediated by numerous fibrotic regulators including some collagens and transforming growth factor (TGF) members (Karsdal et al. 2017, Meng et al. 2016). As shown in Fig. 3A, miR-29a mimics transfection obviously inhibited the protein expression of collagen I and collagen III, whereas miR-29a inhibitors enhanced their levels in human $\mathrm{CB}$ fibroblasts compared with negative control mimics groups (Fig. 3A). The relative protein quantitative analysis of collagen I and collagen III confirmed the regulatory role of miR-29a on the expression of collagens molecule (Fig. 3A). Furthermore, a weaker expression of collagen I, collagen III and alphaSM-actin ( $\alpha$-SMA) mRNA were showed in fibroblasts transfected with miR-29a mimics than cells treated with negative control mimics, but fibroblasts with miR-29a inhibition significantly promoted the transcription level of collagen I, collagen III and $\alpha$-SMA (Fig. $3 \mathrm{~B}$ ). At the same time, we measured the concentration of fibrosisassociated factors including TGF- $\beta 1$, TGF- $\beta 3$ and CTGF in culture mediums. As expected, compared with negative control mimics groups, miR-29a mimics drastically inhibited the secretion of TGF- $\beta 1$, TGF- $\beta 3$ and connective tissue growth factor (CTGF), whereas miR-29a removal accelerated the release of these fibrosisassociated factors in human $\mathrm{CB}$ fibroblasts (Fig. 3C). Thus, these results indicate that miR-29a involved in fibrotic process by obstructing the expression of collagens and the secretion of fibrogenic cytokine in primary human $\mathrm{CB}$ fibroblasts.
A

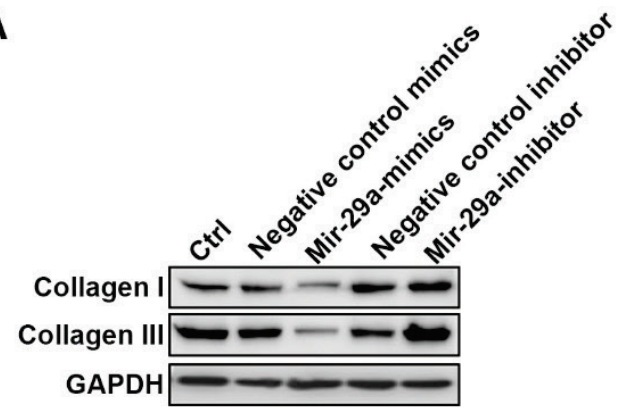

Collagen I/GAPDH

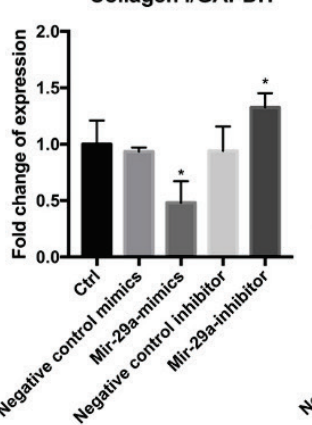

Collagen III/GAPDH

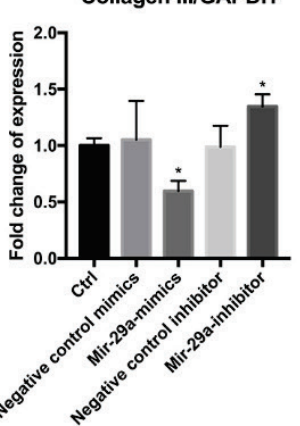

C

B

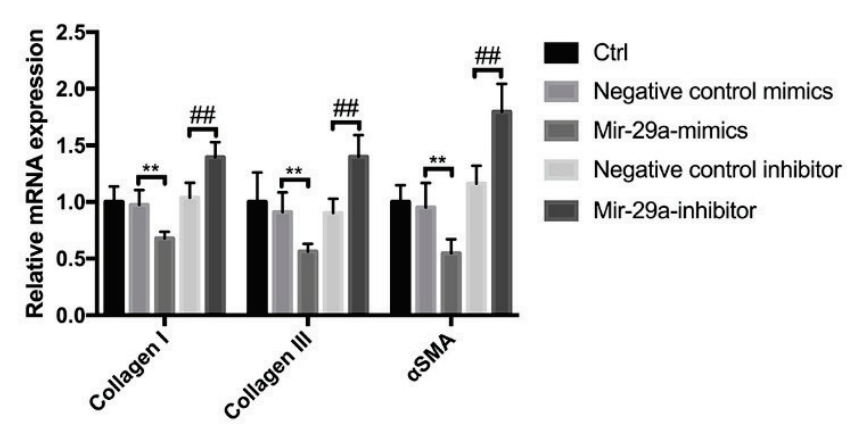

TGF- $\beta 3$

CTGF
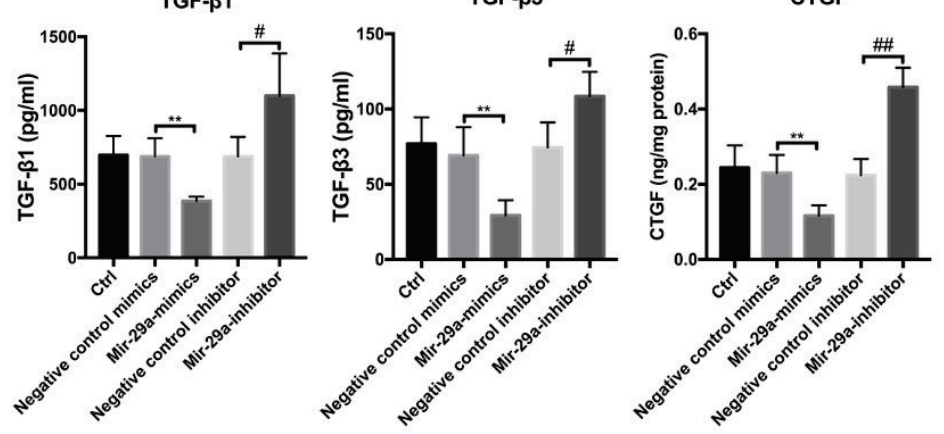

Fig. 3. Effects of miR-29a on fibrosis and collagen deposition in primary human contraction bands fibroblasts. Primary human contraction bands (CB) fibroblasts were transiently transfected with miR-29a mimics ( $50 \mathrm{nM})$, miR-mimic NC, miR-29a inhibitors, or miR-inhibitor NC for $48 \mathrm{~h}$. Then the protein expression of collagen I and collagen III (A) and mRNA expression of collagen I, collagen III and a-SMA (B) were measured by western blotting and GRT-PCR, respectively. Protein expression of collagen I and collagen III were normalized by glyceraldehyde 3-phosphate dehydrogenase (GAPDH). Relative quantitative analysis of protein was proceeded using Quantity One software. Ctrl, control; NC, negative control; a-SMA, alpha-SM-actin. (C) Profibrotic factor TGF- $\beta 1$, TGF- $\beta 3$ and connective tissue growth factor (CTGF) in cellular supernatant were measured by ELISA assay. * indicates miR-29a mimics groups vs. negative control mimics groups. " indicates miR-29a inhibitors groups vs. negative control inhibitor groups. All data were statistically analyzed by

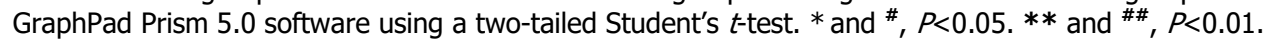

miR-29a inhibits signal transduction of fibrosis by targeting HSP47

HSP47 and TGF- $\beta 1$ have been widely reported in fibrotic related diseases, such as intestinal fibrosis and hepatic fibrosis and so on (Ali et al. 2014, Inoue et al. 2011). To elucidate the regulatory mechanism of miR$29 \mathrm{a}$ on fibrosis in vitro, we evaluated the changes of fibrosis-related signal transduction including HSP47 and 
Smad2/TGF- $\beta 1$ in fibroblasts treated with miR-29a mimics or miR-29a inhibitors. Fibroblasts suffered from miR-29a mimics exhibited more depressed expression of HSP47 and TGF- $\beta 1$ than cells exposed with negative control mimics, and no changes were observed in the expression of phosphorylated Smad2 and total Smad2. However, Fibroblasts exposed with miR-29a inhibitors showed the enhancement of TGF- $\beta 1$ expression, followed by the increase of HSP47, compared with cells transfected with negative control inhibitors (Fig. 4A and B). Further study demonstrated that there were the potential binding sites between miR-29a-3p and
SERPINH1 (HSP47) analyzed by using Starbase database (Fig. S1). Then luciferase reporter assay showed that miR-29a mimics significantly decreased the transcriptional activity of wild-type SERPINH1, but had no impact on its luciferase activity in cells transfected with SERPINH1-3'-UTR-Mut reporter (Fig. 4C). These results suggest that miR-29a blunts the expression of HSP47 by directly targeting its' 3'-UTR, implying that miR-29a negatively regulates the expression of TGF- $\beta 1$ possibly through affecting HSP47, but not Smad2 activity.

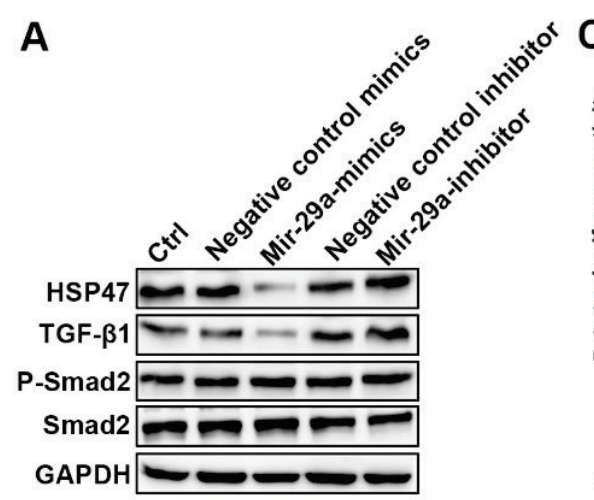

B
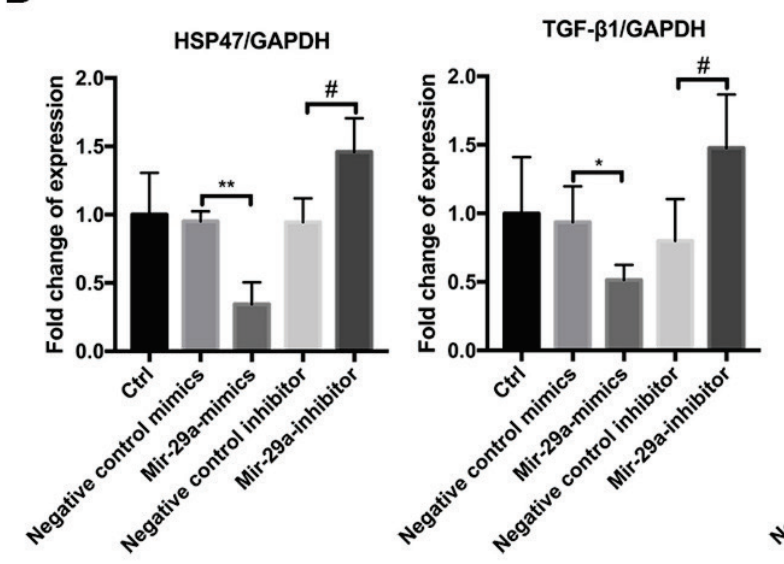

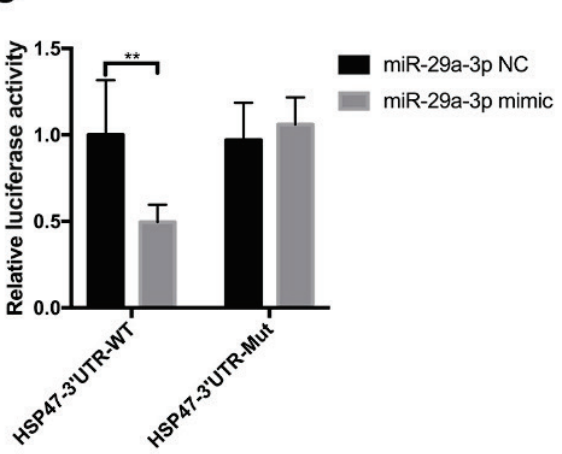

p-smad2/smad2

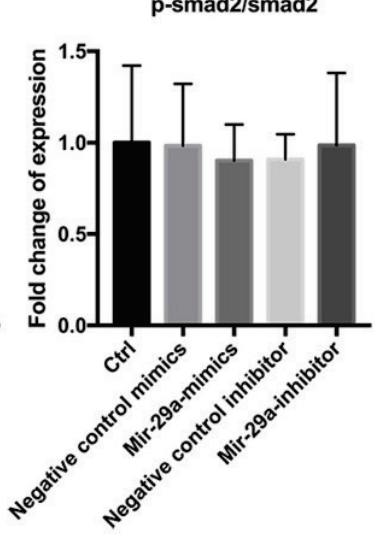

Fig. 4. Effects of miR-29a on HSP47 and subsequent signaling pathway in primary human contraction bands fibroblasts. (A) Human CB fibroblasts were transiently transfected with miR-29a mimic (50 nM), miR-mimic NC, miR-29a inhibitor, or miR-inhibitor $\mathrm{NC}$ for $48 \mathrm{~h}$. Then the protein expression of HSP47, TGF- $\beta 1$, P-Smad2 and Smad2 were analyzed by western blotting. Ctrl, control; NC, negative control. (B) Grayscale quantitation of HSP47, TGF- $\beta 1$ and $\mathrm{P}$-Smad2 protein in primary human $\mathrm{CB}$ fibroblasts. Relative quantitative analysis of protein was proceeded using Quantity One software. (C) Effect of miR-29a on transcription activity of HSP47 as determined by luciferase report assay in fibroblasts. * indicates miR-29a mimics groups vs. negative control mimics groups. \# indicates miR-29a inhibitors groups vs. negative control inhibitor groups. All values were presented as means \pm $\mathrm{SD}$, and these data were statistically analyzed by GraphPad Prism using two-way ANOVA. * and $\#, P<0.05$. $* *$ and ${ }^{\# \#}, P<0.01$.
miR-29a is negatively correlated with HSP47 in gluteal muscle contracture patients

Next, we measured the expression of SERPINHI in contracture band tissue and paired-adjacent tissues from 8 gluteal muscle contracture (GMC) patients. The results showed that SERPINH1 mRNA was much higher in gluteal muscle contracture than adjacent tissues (Fig. 5A). Combined with the results of miR-29a level in contracture band tissue, we discovered that there had a negative association between SERPINH1 and miR-29a expression in contracture bands of GMC patients (Fig. 5B). We also assessed the protein level of HSP47 in contracture band tissue from 8 GMC patients by immunohistochemistry. As shown in Figure 5C, in comparison to adjacent muscle tissues, HSP47-positive cells were robustly enhanced in contracture bands tissue (Fig. 5C). And there was also a significant negative correlation of HSP47-positive cells ratio and miR-29a expression in GMC patients (Fig. 5D).

\section{Discussion}

Circulating microRNAs has been widely used as a useful biomarker in numerous disease including cancer, 
diabetes, and cardiovascular (Lees et al. 2017, Yang et al. 2018, Zhao et al. 2017). In this study, we discovered that circulating miR-29a is downregulated in GMC patients and miR-29a participated in the fibrotic process in human CB fibroblasts, implying that miR-29a might be a helpful biomarker for early diagnosis of GMC.

Many studies in human muscular disorders have reported MiRNAs dysregulation. One hundred and eighty-five miRNAs were enhanced or dwindled in muscle specimens of muscular disorders patients in humans including DMD and Becker muscular dystrophy (BMD), both of which arise from muscular fibrosis (Ardite et al. 2012, Eisenberg et al. 2007, Ohlendieck et al. 2017). Subsequently, miRNAs profiling in blood serum and plasma were abnormal in muscular fibrosisrelated diseases (Cacchiarelli et al. 2011, Hu et al. 2014, Matsuzaka et al. 2014). However, numerous circulating miRNAs were not correspondence with the ones in serum and plasma, for instance that miR-1, miR-133a, and miR-206 were highly abundant in serum but downregulated or modestly upregulated in muscle (Roberts et al. 2012). Fortunately, we found an extraordinary reduced expression of miR-29a in plasma and contraction bands of GMC patients. These findings demonstrate that miR-29a inhibition potentially take part in specific pathological pathways of GMC disease and miR-29a in plasma is perhaps an efficient biomarker for early diagnosis of GMC.
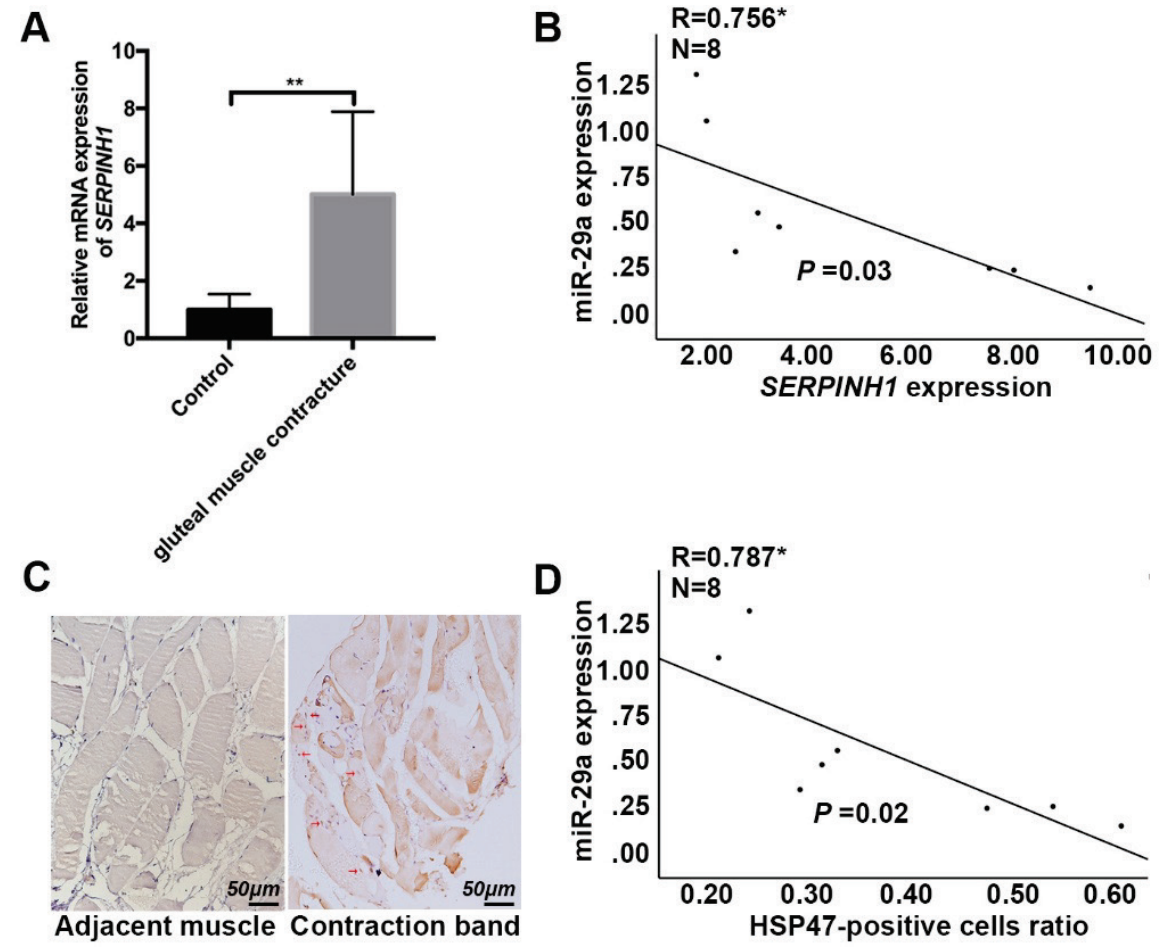

Fig. 5. The correlation between miR29a and HSP47 in Gluteal muscle contracture patients. (A) The expression of SERPINHI mRNA of control and GMC tissues were analyzed by qRT-PCR. (B) The correlation between miR-29a and SERPINHI mRNA in GMC patients by Pearson analysis. (C) HSP47-positive cells determined by immunohistochemistry staining (IHC) using HSP47 antibody. Scale bar: $50 \mu \mathrm{m}$. (D) The correlation between miR-29a and HSP47 positive cells in GMC patients by Pearson analysis. Data in panel $A$ was statistically analyzed by GraphPad Prism using a two-tailed Student's $t$-test. Correlation analysis was performed by Pearson's coefficient using SPSS software. *, $P<0.05$; **, $P<0.01$.
The miRNAs is closely associated with the development of fibrosis in various tissues through controlling the expression of anti- and profibrotic genes, the secretory profibrotic cytokine and transforming growth factor (Bowen et al. 2013). The miR-21 level is elevated in DMD patient's muscle, and miR-21 inhibitor significantly hampers the transcription of fibrosis-related genes, such as COL1A1 and COLI6Al by facilitating the expression of PTEN, resulting in violent reduction of collagen I and VI, and inhibition of fibrosis progression (Heller et al. 2017). Importantly, miR-29b overexpression prevents endometrial fibrosis via blockade of the Sp1-TGF-ß1/Smad-CTGF pathway (Li et al. 2016). miR- 29c suppresses the expression of collagen type I (COL1), collagen type III alpha 1 chain (COL3A1), TGF- $\beta 3$, CDK2 to curb the leiomyoma growth and fibrosis (Chuang et al. 2017). Administrated with miRNA-29c significantly alleviates the accumulation of fibrosis by directly depressing the transcription of COL1A1, followed by the reduction of $\operatorname{Col} 1 \mathrm{~A}, \mathrm{Col} 3 \mathrm{~A}$, fibronectin and Tgfbl expression (Heller et al. 2017). In this study, we detected that miR-29a powerfully inhibited the cell viability of fibroblasts. Besides, miR-29a activation notably activated the fibrotic process by promoting the expression of collagens and the secretory of fibrosisrelated factors. Our data proves that miR-29a-mediated 
the inhibition of cell viability and fibrotic process possibly affects the development of GMC.

HSP47-positive myofibroblasts in the skin significantly induce collagen deposition and aggravate skin fibrosis in chronic graft-versus-host disease (Yamakawa et al. 2018). It is confirmed that miR-29b disrupts collagen structure and collagen maturation in hepatic stellate cells by targeting 3'-UTRs of SERPINH1 (Zhang et al. 2014). MicroRNA-29b-3p also prevents Schistosoma japonicum-induced liver fibrosis by down-regulating the expression of TIMP-1, HSP47, $\alpha$-SMA, COL1A1, and COL3A1 (Tao et al. 2018). Besides, the upregulation of miR-29a is able to alleviate idiopathic pulmonary fibrosis (IPF) by regulating HSP47 (Cushing et al. 2011, Kamikawaji et al. 2016). Here, we identified that miR-29a mimics attenuated fibrosis of $\mathrm{CB}$ fibroblasts by downregulating the expression of TGF- $\beta 1$ via directly binding to HSP47. In addition, miR-29 modification has no impact on the activity of Smad2. These findings reveal that Smad2/TGF- $\beta 1$ pathway is not involved in miR-29a-mediated the improvement of fibrotic processes and HSP47/TGF- $\beta 1$ should be the response for its principal function. Our further study illustrated that there had a negative correlation between miR-29a and HSP47 in GMC patients, which confirmed that miR-29a-mediated the inhibition of fibrosis in fibroblasts should involve with the downregulation of HSP47 in GMC patients. These results firstly and validly suggest an indispensable role for miR-29a in the progression of GMC by interfering fibrosis through regulating HSP47. However, the study is limited by small sample size, and the larger sample size is needed to support the theory postulated in this study. Additionally, effective animal models should be established to further confirmed the new prognostic biomarker of miR-29a in GMC disease.

\section{Conclusions}

In summary, low miR-29a was observed in plasma and contraction bands in GMC patients. Upregulation of miR-29a inhibited the cells viability and fibrosis of fibroblasts through regulating TGF- $\beta 1$ by targeting HSP47. Therefore, circulating miR-29a might be served as a potential early diagnosis index for GMC. Possibly, miR-29a is likely to be a protective factor and novel therapeutic target for GMC by blocking fibrosis progress.

\section{Conflict of Interest}

There is no conflict of interest.

\section{References}

AGGARWAL A, SINGH S, SINGH M, CHAUHAN R: Idiopathic bilateral gluteus maximus contracture: a case report and review of literature. Acta Orthop Belg 71: 493-495, 2005.

AL BAYATI MA, KRAIDY BK: Gluteal muscle fibrosis with abduction contracture of the hip. Int Orthop 40: 447-451, 2016. https://doi.org/10.1007/s00264-015-2836-1

ALI SO, DARWISH HA, ISMAIL NA: Modulatory effects of curcumin, silybin-phytosome and alpha-R-lipoic acid against thioacetamide-induced liver cirrhosis in rats. Chem Biol Interact 216: 26-33, 2014. https://doi.org/10.1016/j.cbi.2014.03.009

AMIN ND, BAI G, KLUG JR, BONANOMI D, PANKRATZ MT, GIFFORD WD, HINCKLEY CA, STERNFELD MJ, DRISCOLL SP, DOMINGUEZ B, LEE KF, JIN X, PFAFF SL: Loss of motoneuron-specific microRNA-218 causes systemic neuromuscular failure. Science 350: 1525-1529, 2015. https://doi.org/10.1126/science.aad2509

ARDITE E, PERDIGUERO E, VIDAL B, GUTARRA S, SERRANO AL, MUÑOZ-CÁNOVES P: PAI-1-regulated miR-21 defines a novel age-associated fibrogenic pathway in muscular dystrophy. J Cell Biol 196: 163-175, 2012. https://doi.org/10.1083/jcb.201105013

BOWEN T, JENKINS RH, FRASER DJ: MicroRNAs, transforming growth factor beta-1, and tissue fibrosis. J Pathol 229: 274-285, 2013. https://doi.org/10.1002/path.4119

CACCHIARELLI D, LEGNINI I, MARTONE J, CAZZELLA V, D'AMICO A, BERTINI E, BOZZONI I: miRNAs as serum biomarkers for Duchenne muscular dystrophy. EMBO Mol Med 3: 258-265, 2011. https://doi.org/10.1002/emmm.201100133 
CHUANG TD, KHORRAM O: Tranilast inhibits genes functionally involved in cell proliferation, fibrosis, and epigenetic regulation and epigenetically induces miR-29c expression in leiomyoma cells. Reprod Sci 24 : 1253-1263, 2017. https://doi.org/10.1177/1933719116682878

CUSHING L, KUANG PP, QIAN J, SHAO F, WU J, LITTLE F, THANNICKAL VJ, CARDOSO WV, LÜ J: miR-29 is a major regulator of genes associated with pulmonary fibrosis. Am J Respir Cell Mol Biol 45: 287-294, 2011. https://doi.org/10.1165/rcmb.2010-0323oc

EISENBERG I, ERAN A, NISHINO I, MOGGIO M, LAMPERTI C, AMATO AA, LIDOV HG, KANG PB, NORTH KN, MITRANI-ROSENBAUM S, FLANIGAN KM, NEELY LA, WHITNEY D, BEGGS AH, KOHANE IS, KUNKEL LM: Distinctive patterns of microRNA expression in primary muscular disorders. Proc Natl Acad Sci U S A 104: 17016-17021, 2007. https://doi.org/10.1073/pnas.0708115104

FRIEDMAN RC, FARH KK, BURGE CB, BARTEL DP: Most mammalian mRNAs are conserved targets of microRNAs. Genome Res 19: 92-105, 2009. https://doi.org/10.1101/gr.082701.108

GRECO S, DE SIMONE M, COLUSSI C, ZACCAGNINI G, FASANARO P, PESCATORI M, CARDANI R, PERBELLINI R, ISAIA E, SALE P, MEOLA G, CAPOGROSSI MC, GAETANO C, MARTELLI F: Common micro-RNA signature in skeletal muscle damage and regeneration induced by Duchenne muscular dystrophy and acute ischemia. FASEB J 23: 3335-3346, 2009. https://doi.org/10.1096/fj.08-128579

HELLER KN, MENDELL JT, MENDELL JR, RODINO-KLAPAC LR: MicroRNA-29 overexpression by adenoassociated virus suppresses fibrosis and restores muscle function in combination with micro-dystrophin. JCI Insight 2: e93309, 2017. https://doi.org/10.1172/jci.insight.93309

HESSE E, TAIPALEENMÄKI H: MicroRNAs in bone metastasis. Curr Osteoporos Rep 17: 122-128, 2019. https://doi.org/10.1007/s11914-019-00510-4

HONG S, PARK K, KIM JH, HAN SH, LEE JB, SEONG GJ: Role of heat shock protein 47 in transdifferentiation of human tenon's fibroblasts to myofibroblasts. BMC Ophthalmol 12: 49, 2012. https://doi.org/10.1186/14712415-12-49

HU J, KONG M, YE Y, HONG S, CHENG L, JIANG L: Serum miR-206 and other muscle-specific microRNAs as non-invasive biomarkers for Duchenne muscular dystrophy. J Neurochem 129: 877-883, 2014. https://doi.org/10.1111/jnc.12662

INOUE K, NAITO Y, TAKAGI T, HAYASHI N, HIRAI Y, MIZUSHIMA K, HORIE R, FUKUMOTO K, YAMADA S, HARUSATO A, HIRATA I, OMATSU T, YOSHIDA N, UCHIYAMA K, ISHIKAWA T, HANDA O, KONISHI H, WAKABAYASHI N, YAGI N, ICHIKAWA H, KOKURA S, YOSHIKAWA T: Daikenchuto, a Kampo medicine, regulates intestinal fibrosis associated with decreasing expression of heat shock protein 47 and collagen content in a rat colitis model. Biol Pharm Bull 34: 1659-1665, 2011. https://doi.org/10.1248/bpb.34.1659

KAMIKAWAJI K, SEKI N, WATANABE M, MATAKI H, KUMAMOTO T, TAKAGI K, MIZUNO K, INOUE H: Regulation of LOXL2 and SERPINH1 by antitumor microRNA-29a in lung cancer with idiopathic pulmonary fibrosis. J Hum Genet 61: 985-993, 2016. https://doi.org/10.1038/jhg.2016.99

KARSDAL MA, NIELSEN SH, LEEMING DJ, LANGHOLM LL, NIELSEN MJ, MANON-JENSEN T, SIEBUHR A, GUDMANN NS, RONNOW S, SAND JM, DANIELS SJ, MORTENSEN JH, SCHUPPAN D: The good and the bad collagens of fibrosis - their role in signaling and organ function. Adv Drug Deliv Rev 121: 43-56, 2017. https://doi.org/10.1016/j.addr.2017.07.014

LEES T, NASSIF N, SIMPSON A, SHAD-KANEEZ F, MARTINIELLO-WILKS R, LIN Y, JONES A, QU X, LAL S: Recent advances in molecular biomarkers for diabetes mellitus: a systematic review. Biomarkers 22: 604-613, 2017. https://doi.org/10.1080/1354750x.2017.1279216

LI J, DU S, SHENG X, LIU J, CEN B, HUANG F, HE Y: MicroRNA-29b inhibits endometrial fibrosis by regulating the Sp1-TGF-beta1/Smad-CTGF axis in a rat model. Reprod Sci 23: 386-394, 2016. https://doi.org/10.1177/1933719115602768

LIU GH, CAO FQ, YANG SH, ZHU JF: Factors influencing the treatment of severe gluteal muscle contracture in children. J Pediatr Orthop B 20: 67-69, 2011. https://doi.org/10.1097/BPB.0b013e328341bcb2

LIU YJ, WANG Y, XUE J, LUI PP, CHAN KM: Arthroscopic gluteal muscle contracture release with radiofrequency energy. Clin Orthop Relat Res 467: 799-804, 2009. https://doi.org/10.1007/s11999-008-0595-7 
LLANO-DIEZ M, ORTEZ CI, GAY JA, ALVAREZ-CABADO L, JOU C, MEDINA J, NASCIMENTO A, JIMENEZMALLEBRERA C: Digital PCR quantification of miR-30c and miR-181a as serum biomarkers for Duchenne muscular dystrophy. Neuromuscul Disord 27: 15-23, 2017. https://doi.org/10.1016/j.nmd.2016.11.003

MATSUZAKA Y, KISHI S, AOKI Y, KOMAKI H, OYA Y, TAKEDA S, HASHIDO K: Three novel serum biomarkers, miR-1, miR-133a, and miR-206 for Limb-girdle muscular dystrophy, facioscapulohumeral muscular dystrophy, and Becker muscular dystrophy. Environ Health Prev Med 19: 452-458, 2014. https://doi.org/10.1007/s12199-014-0405-7

MENG XM, NIKOLIC-PATERSON DJ, LAN HY: TGF-beta: the master regulator of fibrosis. Nat Rev Nephrol 12: 325-338, 2016. https://doi.org/10.1038/nrneph.2016.48

MIZUNO H, NAKAMURA A, AOKI Y, ITO N, KISHI S, YAMAMOTO K, SEKIGUCHI M, TAKEDA S, HASHIDO K: Identification of muscle-specific microRNAs in serum of muscular dystrophy animal models: promising novel blood-based markers for muscular dystrophy. PLoS One 6: e18388, 2011. https://doi.org/10.1371/journal.pone.0018388

MOREIRA SOARES OLIVEIRA B, DURBEEJ M, HOLMBERG J: Absence of microRNA-21 does not reduce muscular dystrophy in mouse models of LAMA2-CMD. PLoS One 12: e0181950, 2017. https://doi.org/10.1371/journal.pone.0181950

MORIN S, DE LA PORTE S, FISZMAN M, KOENIG J: Inhibition of proliferation in 8-week-old mdx mouse muscle fibroblasts in vitro. Differentiation 59: 145-154, 1995. https://doi.org/10.1046/j.1432-0436.1995.5930145.X

OHLENDIECK K, SWANDULLA D: Molecular pathogenesis of Duchenne muscular dystrophy-related fibrosis. (In German) Pathologe 38: 21-29, 2017. https://doi.org/10.1007/s00292-017-0265-1

OLEAS-SANTILLÁN G, BOWEN JR: Anterior hip dislocation from post-injection gluteal muscular fibrosis: case report. JBJS Case Connect 2019. https://doi.org/10.2106/jbjs.cc.18.00250

RAI S, JIN SY, MENG CQ, CHAUDHARY N, TAMANG N, WANG XH, LIU XZ, WANG H, YANG S: Arthroscopic release using $\mathrm{F}$ and $\mathrm{C}$ method versus conventional open release method in the treatment of gluteal muscle contracture: a comparative study. BMC Musculoskelet Disord 18: 113, 2017. https://doi.org/10.1186/s12891-017-1484-6

RAI S, MENG C, WANG X, CHAUDHARY N, JIN S, YANG S, WANG H: Gluteal muscle contracture: diagnosis and management options. SICOT J 3: 1, 2017. https://doi.org/10.1051/sicotj/2016036

ROBERTS TC, BLOMBERG KE, MCCLOREY G, EL ANDALOUSSI S, GODFREY C, BETTS C, COURSINDEL T, GAIT MJ, SMITH CIE, WOOD MJA: Expression analysis in multiple muscle groups and serum reveals complexity in the microRNA transcriptome of the mdx mouse with implications for therapy. Mol Ther Nucleic Acids 1: e39, 2012. https://doi.org/10.1038/mtna.2012.26

SCULLY WF, WHITE KK, SONG KM, MOSCA VS: Injection-induced gluteus muscle contractures: diagnosis with the "reverse ober test" and surgical management. J Pediatr Orthoped 35: 192-198, 2015. https://doi.org/10.1097/bpo.0000000000000238

TAO R, FAN XX, YU HJ, AI G, ZHANG HY, KONG HY, SONG QQ, HUANG Y, HUANG JQ, NING Q: MicroRNA-29b-3p prevents Schistosoma japonicum-induced liver fibrosis by targeting COL1A1 and COL3A1. J Cell Biochem 119: 3199-3209, 2018. https://doi.org/10.1002/jcb.26475

XIAO HB, LIU RH, LING GH, XIAO L, XIA YC, LIU FY, LI J, LIU YH, CHEN QK, LV JL, ZHAN M, YANG SK, KANWAR YS, SUN L: HSP47 regulates ECM accumulation in renal proximal tubular cells induced by TGF-beta1 through ERK1/2 and JNK MAPK pathways. Am J Physiol Renal Physiol 303: F757-F765, 2012. https://doi.org/10.1152/ajprenal.00470.2011

XU J, GENG X, MUHAMMAD H, WANG X, HUANG JZ, ZHANG C, MA X: Comparison of the incisions for the open surgical treatment of gluteal muscle contracture. J Pediatr Orthop B 23: 435-440, 2014. https://doi.org/10.1097/bpb.0000000000000067

YAMAKAWA T, OHIGASHI H, HASHIMOTO D, HAYASE E, TAKAHASHI S, MIYAZAKI M, MINOMI K, ONOZAWA M, NIITSU Y, TESHIMA T: Vitamin A-coupled liposomes containing siRNA against HSP47 ameliorate skin fibrosis in chronic graft-versus-host disease. Blood 131: 1476-1485, 2018. https://doi.org/10.1182/blood-2017-04-779934 
YANG F, CHEN Q, HE S, YANG M, MAGUIRE EM, AN W, AFZAL TA, LUONG LA, ZHANG L, XIAO Q: miR-22 is a novel mediator of vascular smooth muscle cell phenotypic modulation and neointima formation. Circulation 137: 1824-1841, 2018. https://doi.org/10.1161/circulationaha.117.027799

YANG J, ZHENG J, WU L, SHI M, ZHANG H, WANG X, XIA N, WANG D, LIU X, YAO L, LI Y, DOU K: NDRG2 ameliorates hepatic fibrosis by inhibiting the TGF-beta1/Smad pathway and altering the MMP2/TIMP2 ratio in rats. PLoS One 6: e27710, 2011. https://doi.org/10.1371/journal.pone.0027710

ZANOTTI S, GIBERTINI S, BLASEVICH F, BRAGATO C, RUGGIERI A, SAREDI S, FABBRI M, BERNASCONI P, MAGgi L, MANTEGAZZA R, MORA M: Exosomes and exosomal miRNAs from muscle-derived fibroblasts promote skeletal muscle fibrosis. Matrix Biol 74: 77-100, 2018. https://doi.org/10.1101/267963

ZANOTTI S, GIBERTINI S, CURCIO M, SAVADORI P, PASANISI B, MORANDI L, CORNELIO F, MANTEGAZZA R, MORA $\mathrm{M}$ : Opposing roles of miR-21 and miR-29 in the progression of fibrosis in Duchenne muscular dystrophy. Biochim Biophys Acta 1852: 1451-1464, 2015. https://doi.org/10.1016/j.bbadis.2015.04.013

ZHANG X, JIANG X, HE F, LIANG Z, YOU T, JIN D, ZHANG W: Arthroscopic revision release of gluteal muscle contracture after failed primary open surgery. Int Orthop 41: 1521-1526, 2017. https://doi.org/10.1007/s00264016-3354-5

ZHANG X, MA Y, YOU T, TIAN X, ZHANG H, ZHU Q, ZHANG W: Roles of TGF-beta/Smad signaling pathway in pathogenesis and development of gluteal muscle contracture. Connect Tissue Res 56: 9-17, 2015. https://doi.org/10.3109/03008207.2014.964400

ZHANG Y, GHAZWANI M, LI J, SUN M, STOLZ DB, HE F, FAN J, XIE W, LI S: MiR-29b inhibits collagen maturation in hepatic stellate cells through down-regulating the expression of HSP47 and lysyl oxidase. Biochem Biophys Res Commun 446: 940-944, 2014. https://doi.org/10.1016/j.bbrc.2014.03.037

ZHAO CG, HE XJ, LU B, LI HP, KANG AJ: Increased expression of collagens, transforming growth factor-beta1, and -beta3 in gluteal muscle contracture. BMC Musculoskelet Disord 11: 15, 2010. https://doi.org/10.1186/14712474-11-15

ZHAO CG, HE XJ, LU B, LI HP, WANG D, ZHU ZZ: Classification of gluteal muscle contracture in children and outcome of different treatments. BMC Musculoskelet Disord 10: 34, 2009. https://doi.org/10.1186/1471-2474$10-34$

ZHAO Y, SONG Y, YAO L, SONG G, TENG C: Circulating microRNAs: Promising biomarkers involved in several cancers and other diseases. DNA Cell Biol 36: 77-94, 2017. https://doi.org/10.1089/dna.2016.3426 